Dokuz Eylül Üniversitesi-Mühendislik Fakültesi

Fen ve Mühendislik Dergisi

Cilt 20, Sayı 59, Mayıs, 2018
Dokuz Eylul University-Faculty of Engineering Journal of Science and Engineering Volume 20, Issue 59, May, 2018

DOI: $10.21205 /$ deufmd. 2018205928

\title{
Sodyum Boratlardan Potasyum Borat Sentezi: Reaksiyon Koşullarının Optimizasyonu
}

\section{Emek MÖRÖYDOR DERUN ${ }^{* 1}$}

1 Yildiz Technical University, Faculty of Chemical and Metallurgical

Engineering, Department of Chemical Engineering, 34220, Istanbul, Turkey.

ORCID: 0000-0002-8587-2013

(Alınış / Received: 16.02.2017, Kabul / Accepted: 02.01.2018, Online Yayınlanma / Published Online: 15.05.2018)

Anahtar Kelimeler Özet: Potasyum boratlar; spesifik özelliklerinden dolayı metal Potasyum borat, rafine etme endüstrisinde, yapı bileşiklerinde, fiberglas malzeme Hidrotermal sentez, olarak, yağlayıcılarda olduğu gibi doğrusal olmayan optik Karakterizasyon, XRD malzemelerde kullanılabilen önemli bileşiklerdir. Bu çalışmada, 01-072-1688 toz difraksiyon kart numarasina sahip spesifik bir potasyum pentaborat $\left(\mathrm{KB}_{5} \mathrm{O}_{8} \cdot 4 \mathrm{H}_{2} \mathrm{O}\right)$ olan santit minerali hidrotermal metotla \%90-96 verimle sentezlenmiștir. Potasyum kaynağı olarak potasyum klorür $(\mathrm{KCl})$ ve bor kaynağı olarak tinkalkonit $\left(\mathrm{Na}_{2} \mathrm{~B}_{4} \mathrm{O}_{7} \cdot 5 \mathrm{H}_{2} \mathrm{O}\right)$, boraks $\left(\mathrm{Na}_{2} \mathrm{~B}_{4} \mathrm{O}_{7} \cdot 10 \mathrm{H}_{2} \mathrm{O}\right)$, borik asit $\left(\mathrm{H}_{3} \mathrm{BO}_{3}\right)$ ve bor oksit $\left(\mathrm{B}_{2} \mathrm{O}_{3}\right)$ kullanılmıştır. Reaksiyon sıcaklıkları 60 ve $90^{\circ} \mathrm{C}$, reaksiyon süreleri 15 - 120 dakika aralığında belirlenmiştir. Sentezlenen mineraller X-Işını Kırınımı Difraktometresi (XRD), Fourier transform infrared (FT-IR) ve Raman spektroskopileri ve yüzey morfolojilerinin incelenmesi içinde taramalı elektron mikroskobu (SEM) kullanılmıştır.

\section{Potassium Borate Synthesis From Sodium Borates: Optimization Of} Reaction Conditions

Keywords Potassium borates, Hydrothermal synthesis, Characterization, XRD
Abstract: Potassium borates are the important compounds due to their specific properties and can be used as in metal refining industry, in construction compounds, as fiberglass material, as in lubricants and in non-linear optical materials. In this study, a specific potassium pentaborate $\left(\mathrm{KB}_{5} \mathrm{O}_{8} \cdot 4 \mathrm{H}_{2} \mathrm{O}\right)$ compound of santite mineral, with a powder diffraction number of 01-0721688 was synthesized through a hydrothermal route with reaction efficiencies between $90-96 \%$. The main potassium source was potassium chloride $(\mathrm{KCl})$ and the boron sources were tincalconite $\left(\mathrm{Na}_{2} \mathrm{~B}_{4} \mathrm{O}_{7} \cdot 5 \mathrm{H}_{2} \mathrm{O}\right)$, borax $\left(\mathrm{Na}_{2} \mathrm{~B}_{4} \mathrm{O}_{7} \cdot 10 \mathrm{H}_{2} \mathrm{O}\right)$, boric acid $\left(\mathrm{H}_{3} \mathrm{BO}_{3}\right)$ and boron oxide $\left(\mathrm{B}_{2} \mathrm{O}_{3}\right)$. Reaction temperatures were determined between 60 and $90^{\circ} \mathrm{C}$ and reaction times between 15 and 120 minutes. Synthesized minerals were characterized by Xray diffraction (XRD), Fourier transform infrared (FT-IR) and Raman spectroscopies and surface morphologies were determined by scanning electron microscopy (SEM). 
E., Derun, Möröydor, / Potassium Borate Synthesis From Sodium Borates: Optimization Of Reaction Conditions

*Corresponding Author: moroydor@yildiz.edu.tr

\section{Introduction}

Boron is found in nature as the complexes of metallic and non-metallic atoms. These complexes are called boron minerals and there are more than 230 boron minerals in nature. Each type of boron minerals is preferred in different applications according to its physical and chemical features. Potassium borates are generally used in the production of inorganic boron compounds as raw material. As a reducing agent, it is also used in photography, in metal refining and in the preparation of antibiotics and vitamins. As a potassium borate compound, potassium pentaborate $\left(\mathrm{KB}_{5} \mathrm{O}_{8} \cdot 4 \mathrm{H}_{2} \mathrm{O}\right)$ shows important nonlinear optical features. This type of borate is also known as "santite" mineral. It has the orthorhombic lattice system and its crystals are at the appearance of transparent and colourless aggregates [1-4].

Potassium borates can be produced at dehydrated structure using the solidstate method or at hydrous structure using the liquid-state method. Youngman and Zwanziger studied the structural changes during the $\left(\mathrm{K}_{2} \mathrm{O}\right)_{\mathrm{x}} \cdot\left(\mathrm{B}_{2} \mathrm{O}_{3}\right)_{1-\mathrm{x}}$ formation using the raw materials of boric acid, elemental boron and potassium carbonate at the reaction temperature of $1000^{\circ} \mathrm{C}$ [5]. Colourless crystals of $\mathrm{K}\left[\mathrm{B}_{5} \mathrm{O}_{7}(\mathrm{OH})_{2}\right]$ were synthesized using the mixture of $\mathrm{GaO}(\mathrm{OH}), \mathrm{H}_{3} \mathrm{BO}_{3}, \mathrm{KNO}_{3}$ at the reaction temperature $210^{\circ} \mathrm{C}$ for 3 days [6]. Wang et al., obtained $\mathrm{KB}_{3} \mathrm{O}_{4}(\mathrm{OH})_{2}$ from $\mathrm{K}_{2} \mathrm{~B}_{4} \mathrm{O}_{7} \cdot 4 \mathrm{H}_{2} \mathrm{O}$ phase at $165^{\circ} \mathrm{C}$ for 10 days [7]. $\mathrm{K}_{4}\left[\mathrm{~B}_{10} \mathrm{O}_{15}(\mathrm{OH})_{4}\right]$ was produced using the raw materials of pyridine, $\mathrm{H}_{3} \mathrm{BO}_{3}$ and $\mathrm{KOH}$ at $170^{\circ} \mathrm{C}$ for 7 days; the standard molar enthalpy of this type potassium borate was determined as $8651 \mathrm{~kJ} / \mathrm{mol}[8,9]$. As a different kind of potassium borate, $\mathrm{KB}_{3} \mathrm{O}_{5} \cdot 3 \mathrm{H}_{2} \mathrm{O}$ was obtained from the reaction of
$\mathrm{K}_{2} \mathrm{~B}_{4} \mathrm{O}_{7} \cdot 4 \mathrm{H}_{2} \mathrm{O}$ and $\mathrm{KB}_{5} \mathrm{O}_{8} \cdot 4 \mathrm{H}_{2} \mathrm{O}$ in liquid state [10]. Asensio et al., studidfed thermal behaviour of santite mineral and determined the kinetic parameters of dehydration reaction [3].

As it is seen from the literature, general synthesis procedure of potassium borate is hydrothermal synthesis and it involves the steps of raw material dissolution in liquid medium, reaction at the temperatures higher than $165^{\circ} \mathrm{C}$ and time longer than 3 days $[5-10,13]$. The aim of this research is to optimize the reaction conditions to potassium borate synthesis at lower temperatures and times. For this purpose, synthesis parameters were selected to focus on the wide ranges of $60-90^{\circ} \mathrm{C}$ and $15-120$ min, together with the achievement of high reaction yields from the samples. Prepared samples were identified using the technique of X-ray diffractometer (XRD) and characterized using the spectroscopic methods of Fourier transform infrared (FT-IR) and Raman. Morphological properties were investigated with scanning electron microscope (SEM).

\section{Material and Method}

\subsection{Raw Material Preparation and Identification}

The potassium source used in experiments was potassium chloride $(\mathrm{KCl})$, retrieved from Sigma-Aldrich, (CAS Number P9333, with a minimum purity of $99 \%$ ) and used without any pre-treatment. Boric acid $\left(\mathrm{H}_{3} \mathrm{BO}_{3}\right)$, boron oxide $\left(\mathrm{B}_{2} \mathrm{O}_{3}\right)$ were determined as the boron sources and borax $\left(\mathrm{Na}_{2} \mathrm{~B}_{4} \mathrm{O}_{7} \cdot 10 \mathrm{H}_{2} \mathrm{O}\right)$ and tincalconite $\left(\mathrm{Na}_{2} \mathrm{~B}_{4} \mathrm{O}_{7} \cdot 5 \mathrm{H}_{2} \mathrm{O}\right)$ were used as both boron and sodium sources. The raw materials were crushed, grinded and sieve to reduce particle size below 75 $\mu \mathrm{m}$.

The raw materials were identified by a PANalytical XPert Pro (PANalytical, 
E., Derun, Möröydor, / Potassium Borate Synthesis From Sodium Borates: Optimization Of Reaction Conditions

Almelo, The Netherlands) X-ray diffractometer (XRD) by using $\mathrm{Cu}-\mathrm{K}_{\alpha}$ radiation. Operating parameters of the device were $2 \theta$ range of $7^{\circ}-90^{\circ}, 45 \mathrm{kV}$ and $40 \mathrm{~mA}(\lambda=1.53 \mathrm{~nm})$.

\subsection{Synthesis Procedure and Characterization of Samples}

In hydrothermal synthesis, different sets were designed in potassium borate synthesis, using different boron and sodium sources. In all sets, $\mathrm{KCl}$ was designated as the potassium source. Each set was explained with the codes of "Kc-T-H", "Kc-T-B", "Kc-Bx-H" and "Kc-Bx-B" for Set-1, 2, 3 and 4, respectively. Each sample was encoded by letters (Kc: $\mathrm{KCl}, \mathrm{T}$ : $\mathrm{Na}_{2} \mathrm{~B}_{4} \mathrm{O}_{7} \cdot 5 \mathrm{H}_{2} \mathrm{O}, \mathrm{Bx}$ : $\mathrm{Na}_{2} \mathrm{~B}_{4} \mathrm{O}_{7} \cdot 10 \mathrm{H}_{2} \mathrm{O}, \mathrm{H}: \mathrm{H}_{3} \mathrm{BO}_{3}$ and $\mathrm{B}: \mathrm{B}_{2} \mathrm{O}_{3}$ ), reaction temperature, and reaction time. For instance, the sample synthesized at $80^{\circ} \mathrm{C}-15$ minutes in Set1 was coded as "Kc-T-H-80-15".

Mole ratios (mole: mole) of raw materials were determined from the pre-experiments as 1:7 for all sets. The moles of potassium and boron sources is given in Table 1 . The raw materials at the suitable mole ratios were taken to the glass reaction vessel $(100 \mathrm{ml})$. The reaction temperature and time were determined in the ranges of $60-90^{\circ} \mathrm{C}$ and 15-120 minutes.

$\mathrm{KCl}$ was selected as key component for the reaction yields. Calculation for the reaction yields was given in the study of Asensio et al. [3]. Expected reactions for each set were presented in (1)-(4):

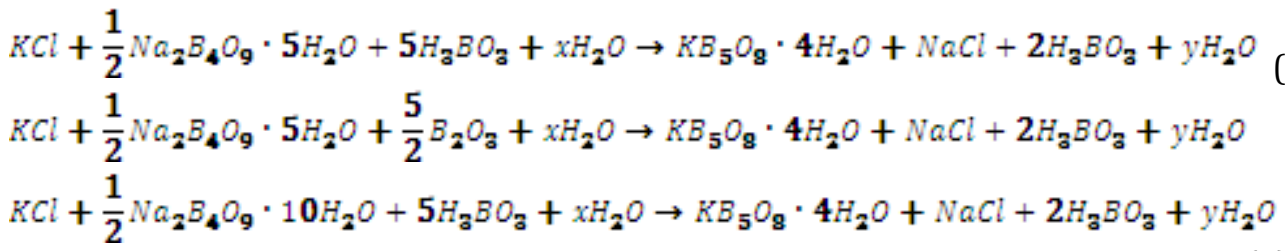

$\mathrm{KCl}+\frac{1}{2} \mathrm{Na}_{2} \mathrm{~B}_{4} \mathrm{O}_{9} \times 1 \mathrm{OH}_{2} \mathrm{O}+\frac{5}{2} \mathrm{~B}_{2} \mathrm{O}_{3}+x \mathrm{H}_{2} \mathrm{O} \rightarrow \mathrm{KB}_{5} \mathrm{O}_{8} \times 4 \mathrm{H}_{2} \mathrm{O}+\mathrm{NaCl}+2 \mathrm{H}_{3} \mathrm{BO}_{3}+\mathrm{yH}_{2} \mathrm{O}$

Table 1. Moles of raw materials used in experiments

\begin{tabular}{lllll}
\hline Sources & SET- & SET-2 & SET-3 & SET-4 \\
\hline $\mathrm{KCl}$ & 0.0184 & 0.0184 & 0.0184 & 0.0184 \\
\hline $\mathrm{Na}_{2} \mathrm{~B}_{4} \mathrm{O}_{7} \cdot 5 \mathrm{H}_{2} \mathrm{O}$ & 0.0092 & 0.0092 & - & - \\
\hline $\mathrm{Na}_{2} \mathrm{~B}_{4} \mathrm{O}_{7} \cdot 10 \mathrm{H}_{2} \mathrm{O}$ & - & - & 0.0092 & 0.0092 \\
\hline $\mathrm{H}_{3} \mathrm{BO}_{3}$ & 0.0927 & - & 0.0927 & - \\
\hline $\mathrm{B}_{2} \mathrm{O}_{3}$ & - & 0.0463 & - & 0.0463 \\
\hline
\end{tabular}

Synthesized potassium borates were identified with XRD. The XRD parameters were remained same as defined in section 2.1. Characteristic band values of identified samples were analysed using a Perkin Elmer FT-IR with universal attenuation total reflectance (ATR) sampling accessory with a diamond/ZnSe crystal. The measurement range of $1800-650 \mathrm{~cm}^{-1}$, scan number of 4 , and resolution of
$4 \mathrm{~cm}^{-1}$ were set fixed. For further analysis, Perkin Elmer Brand Raman Station $400 \mathrm{~F}$ was used for Raman spectroscopy. In these analyses, the exposure time was 4 seconds and the number of exposures was 4. Measurement range was 1800$250 \mathrm{~cm}^{-1}$ and the data interval was $2 \mathrm{~cm}^{-1}$. A CamScan Apollo 300 field- 
E., Derun, Möröydor, / Potassium Borate Synthesis From Sodium Borates: Optimization Of Reaction Conditions

emission SEM $(15 \mathrm{kV}$, magnification: 2000) was used to study the surface morphology.

\section{Results}

\subsection{Raw Material Characterization Results}

The potassium source was identified as the sylvite $(\mathrm{KCl})$ with powder diffraction file (pdf) number of 00-041-1476. The boron and sodium sources used in the experiments were found to be boric acid $\left(\mathrm{H}_{3} \mathrm{BO}_{3}\right)$, boron oxide $\left(\mathrm{B}_{2} \mathrm{O}_{3}\right)$ borax $\left(\mathrm{Na}_{2} \mathrm{~B}_{4} \mathrm{O}_{7} \cdot 10 \mathrm{H}_{2} \mathrm{O}\right)$ and tincalconite $\left(\mathrm{Na}_{2} \mathrm{~B}_{4} \mathrm{O}_{7} \cdot 5 \mathrm{H}_{2} \mathrm{O}\right)$ with powder diffraction file (pdf) numbers of 01-073-2158, 00006-0297, 01-075-1078 and 00-0070277, respectively.

\subsection{XRD Results of Samples}

The XRD results of synthesized potassium borates are given in Table 2 . According to the XRD results, obtained samples were identified as "santite $\mathrm{KB}_{5} \mathrm{O}_{8} \cdot 4 \mathrm{H}_{2} \mathrm{O}$ " mineral with the pdf number of 01-1072-1688.

In all sets, the higher XRD score were obtained at the reaction temperature of $60^{\circ} \mathrm{C}$. This situation may be explained with the increasing reaction temperature adversely effects the crystal structure of potassium borate hydrate. In Set-1 (Kc-T-H), XRD score of 23 was obtained at the product of Kc-TH-90-120. The highest XRD score was 81 and it was obtained at the reaction temperature of $60^{\circ} \mathrm{C}$ for 15 minutes (Kc$\mathrm{T}-\mathrm{H}-60-15)$. As it can be seen from Table 2 , reaction time was as important as reaction temperature. In the XRD scores of the samples synthesized in Set 2 (Kc$\mathrm{T}-\mathrm{B})$, the reaction time had more effect than the temperature. The optimum sample of this set was Kc-T-B-60-15 and its XRD score was 70.

In Set-3 (Kc-Bx-H), the reaction temperature had more effect than the reaction time. The optimum sample was obtained at Kc-Bx-H-60-30 with the XRD score 65. In Set-4 (Kc-Bx-B), reaction time had minor effects on potassium borate formation. The optimum sample of this set was Kc-Bx-B-60-120 with the XRD score of 56. According XRD results from Table 2, Set-1 was more suitable for the santite $-\mathrm{KB}_{5} \mathrm{O}_{8} \cdot 4 \mathrm{H}_{2} \mathrm{O}$ formation. XRD patterns of optimum products are presented in Figure 1. The characteristic peaks [h k l ( $\left.\left.\mathrm{d}_{\text {spacing }}\right)\right]$ of santite can be seen at the $2 \theta$ positions of $14.92^{\circ}\left[\begin{array}{lll}1 & 1 & 1\end{array}\right.$

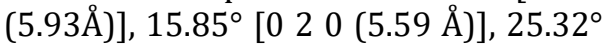
[0 22 (3.51 $\AA$ ) ], $26.59^{\circ}$ [1 22 (3.35 Å)], $32.35^{\circ}$ [4 00 (2.77 $\AA$ )] and $41.52^{\circ}$ [4 22 $(2.17 \AA)]$. The results correlate with the study of Asensio et al. [3].

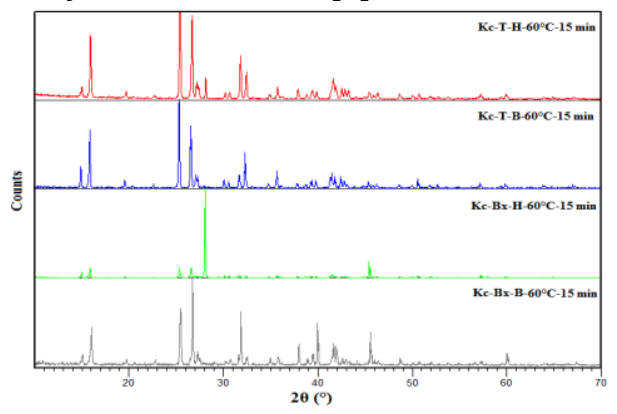

Figure 1. XRD patterns of optimum samples in each set

\subsection{FT-IR and Raman Results of Samples}

The boron atom is possessed of two types of coordination modes of triangularly coordinated boron atoms $\left(\mathrm{B}_{(3)}-0\right)$ and tetrahedrally coordinated boron atoms $\left(\mathrm{B}_{(4)}-\mathrm{O}\right)$. FT-IR spectrum of optimum samples in each set is presented in Figure 2. According to the FT-IR results, the first characteristic band value in the range of 1331 - 1335 $\mathrm{cm}^{-1}$ could be explained with the asymmetric stretching of $\mathrm{B}_{(4)}-\mathrm{O}$. Bending mode of $\mathrm{B}-\mathrm{O}-\mathrm{H}$ was seen at the band value of $1245 \mathrm{~cm}^{-1}$. The characteristic band between 1095-1022 $\mathrm{cm}^{-1}$ belonged to asymmetric stretching of $\mathrm{B}_{(4)}-\mathrm{O}$. Symmetric stretching of $\mathrm{B}_{(3)}-\mathrm{O}$ was observed at around $915 \mathrm{~cm}^{-1}$ whereas symmetric stretching of $\mathrm{B}_{(3)}-\mathrm{O}$ was seen 
E., Derun, Möröydor, / Potassium Borate Synthesis From Sodium Borates: Optimization Of Reaction Conditions

at $781 \mathrm{~cm}^{-1}$. Last characteristic with the bending of $\mathrm{B}_{(3)}-0$. vibrations at $690 \mathrm{~cm}^{-1}$ can be explained

Table 2. XRD scores of samples

\begin{tabular}{|c|c|c|c|c|c|}
\hline $\begin{array}{l}\text { Reaction } \\
\text { Temperature }\left({ }^{\circ} \mathrm{C}\right)\end{array}$ & $\begin{array}{l}\text { Reaction } \\
\text { Time (min) }\end{array}$ & $\begin{array}{l}\text { SET-1 } \\
\text { (Kc-T-H) }\end{array}$ & $\begin{array}{l}\text { SET-2 } \\
\text { (Kc-T-B) }\end{array}$ & $\begin{array}{l}\text { SET-3 (Kc- } \\
\text { Bx-H) }\end{array}$ & $\begin{array}{l}\text { SET-4 } \\
\text { (Kc-Bx-B) }\end{array}$ \\
\hline \multirow{4}{*}{60} & 15 & 81 & 70 & 65 & 56 \\
\hline & 30 & 71 & 52 & 64 & 47 \\
\hline & 60 & 56 & 55 & 47 & 51 \\
\hline & 120 & 78 & 56 & 59 & 53 \\
\hline \multirow{4}{*}{70} & 15 & 50 & 42 & 35 & 38 \\
\hline & 30 & 42 & 31 & 35 & 44 \\
\hline & 60 & 44 & 32 & 29 & 41 \\
\hline & 120 & 51 & 31 & 26 & 23 \\
\hline \multirow{4}{*}{80} & 15 & 59 & 46 & 40 & 37 \\
\hline & 30 & 41 & 32 & 32 & 31 \\
\hline & 60 & 45 & 45 & 33 & 36 \\
\hline & 120 & 59 & 32 & 45 & 30 \\
\hline \multirow{4}{*}{90} & 15 & 45 & 31 & 24 & 42 \\
\hline & 30 & 32 & 36 & 27 & 30 \\
\hline & 60 & 30 & 43 & 35 & 32 \\
\hline & 120 & 23 & 42 & 21 & 42 \\
\hline
\end{tabular}

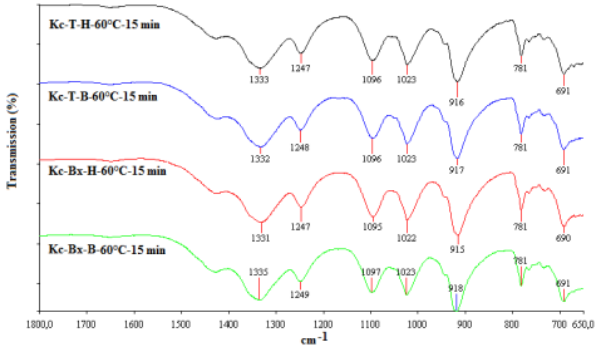

Figure 2. FT-IR spectra of optimum samples in each set

Raman spectrum of optimum samples in each set is presented in Figure 3. In Raman results, the band values at 917 $\mathrm{cm}^{-1}$ can be explained with the symmetric stretching of $\mathrm{B}_{(3)}-\mathrm{O}$. the symmetric stretching of $\mathrm{B}_{(4)}-\mathrm{O}$ was observed at $765 \mathrm{~cm}^{-1}$. The peak around $556 \mathrm{~cm}^{-1}$ was observed to the symmetric vibration of the pentaborate anion $\left(\left(\mathrm{B}_{5} \mathrm{O}_{6}(\mathrm{OH})_{4}\right)^{-}\right)$. Bending of $\mathrm{B}_{(4)}-\mathrm{O}$ was seen in the range of $509-296 \mathrm{~cm}^{-1}$.

The obtained characteristic bands were in accordance with the results obtained by Jun et al. and Yongzhong et al [14, 15].

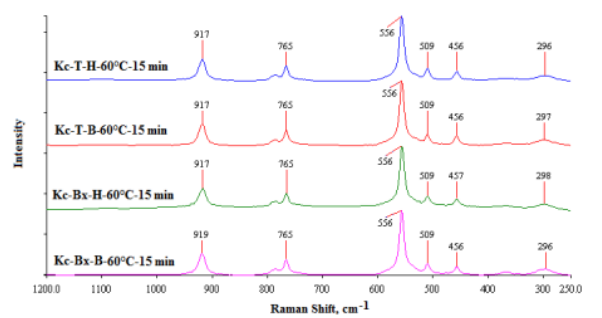

Figure 3. Raman spectra of optimum samples in each set

\subsection{SEM Morphologies of Samples}

SEM morphologies of optimum samples in each set are presented in Figure 4. In Set-1 and 4, potassium borate particles were seen as angular and polyhedral aggregates. Particle sizes of Kc-T-H60-15 and Kc-Bx-B-60-15 were in the range of $292 \mathrm{~nm}-1.80 \mu \mathrm{m}$ and $293 \mathrm{~nm}$ - $1.32 \mu \mathrm{m}$, respectively. The unshaped particle formation were seen at the samples in Set-2 and 3. The fine particles were observed in the range of $261 \mathrm{~nm}-1.24 \mu \mathrm{m}$ in Set-2 (Kc-T-B-60$15)$, whereas the coarse particles were 
E., Derun, Möröydor, / Potassium Borate Synthesis From Sodium Borates: Optimization Of Reaction Conditions

observed in the range of $308 \mathrm{~nm}-2.52$ $\mu \mathrm{m}$ in Set-2 (Kc-Bx-H-60-15).

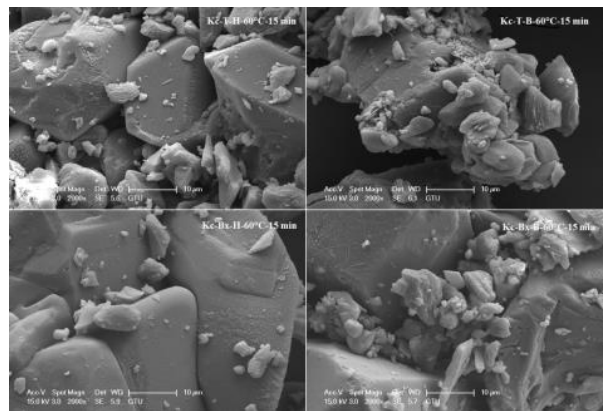

Figure 4. SEM morphologies of optimum samples in each set

\subsection{Reaction Yield Results}

Reaction yields results of samples are presented in Figure 5. According to the results, reaction yields increase with the increasing reaction temperature and time in all sets. The higher reaction yields were observed at the reaction temperature of $90^{\circ} \mathrm{C}$ and reaction time of 120 minutes. There were minor differences among the samples of sets at $90^{\circ} \mathrm{C}$. The highest reaction yield was observed as 96\% in Set-3 (Kc-Bx-H-90$120)$, while the lowest reaction yield was observed as $90 \%$ in Set-2 (Kc-T-B90-120).

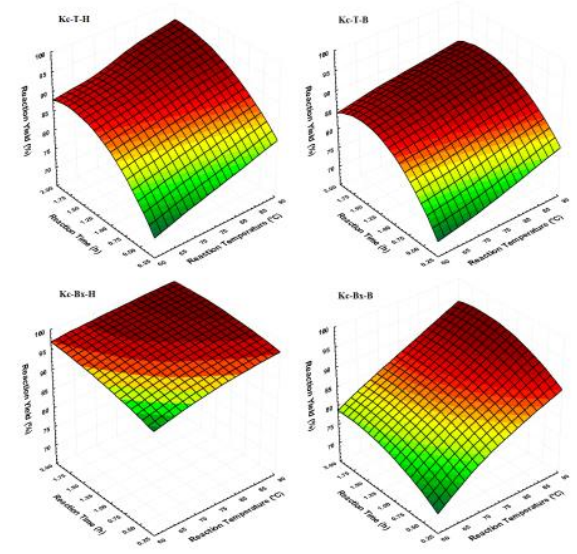

Figure 5. Reaction yields of samples

\section{Discussion and Conclusion}

Synthesis and characterization of potassium borates were examined in this study. Experimental results indicated the possibility of potassium borate hydrate synthesis at lower reaction temperatures and times. According to the XRD results, synthesized samples were identified as "santite $-\mathrm{KB}_{5} \mathrm{O}_{8} \cdot 4 \mathrm{H}_{2} \mathrm{O}$ ". The highest XRD peaks were observed using the raw materials of $\mathrm{KCl}, \mathrm{Na}_{2} \mathrm{~B}_{4} \mathrm{O}_{7} \cdot 5 \mathrm{H}_{2} \mathrm{O}$ and $\mathrm{H}_{3} \mathrm{BO}_{3}$. Characteristic vibration between the boron and oxygen atoms were determined using the FT-IR and Raman spectroscopies. In this set, angular and polyhedral aggregates were seen in the particle distribution of $292 \mathrm{~nm}-2.52$ $\mu \mathrm{m}$.

\section{Acknowledgment}

The author would like to express her deepest gratitude to Dr. Seyhun Kipcak, Dr. F. Tugce Senberber and Gokce Karabulut for their contribution to the study.

\section{References}

[1] Adair, A. 2007. Understanding the elements of Periodic Table: Boron, The Rosen Publishing Group, United States.

[2] Beatty, R. 2006. The Elements: Boron, Marshall Cavendish, New York.

[3] Asensio, M.O., Yildirim, M., Senberber F.T., Kipcak A.S. and Derun, E.M. 2016. Thermal dehydration kinetics and characterization of synthesized potassium borates, Research on Chemical Intermediates, vol. 42, pp. 4859-4878.

[4] Kipcak, A.S., Gunal, M., Ila, S., Yildirim, M., Piskin, M.B and Derun, E.M. 2015. Determination Optimum $\mathrm{B}_{2} \mathrm{O}_{3}, \quad \mathrm{KCl}$ and $\mathrm{NaOH}$ Molar Ratios in the Synthesis of Potassium Borates, Celal Bayar 
E., Derun, Möröydor, / Potassium Borate Synthesis From Sodium Borates: Optimization Of Reaction Conditions

University Journal of Science, vol. 11, pp. 409-412.

[5] Youngman, R.E. and Zwanziger, J.W. 1996. Network Modification in Potassium Borate Glasses: Structural Studies with NMR and Raman Spectroscopies, The Journal of Physical Chemistry, vol. 100, pp. 16720-16728.

[6] $\mathrm{Wu}, \quad$ Q. 2011. Potassium pentaborate, Acta Crystallographica, vol. E67, pp. sup-1 - sup-7.

[7] Wang. G.M., Sun, Y.Q., Zheng, S.T. and Yang, G.Y. 2006. Synthesis and Crystal Structure of a Novel Potassium Borate with an Unprecedented $\quad\left[\mathrm{B}_{12} \mathrm{O}_{16}(\mathrm{OH})_{8}\right]^{4-}$ Anion, Zeitschrift für anorganische und allgemeine Chemie, vol. 632, pp. 1586-1590.

[8] Zhang, H.X., Zhang, J., Zheng, S.T. and Yang, G.Y. 2004. Two New Potassium Borates, $\mathrm{K}_{4} \mathrm{~B}_{10} \mathrm{O}_{15}(\mathrm{OH})_{4}$ with Stepped Chain and $\mathrm{KB}_{5} \mathrm{O}_{7}(\mathrm{OH}) 2 . \mathrm{H}_{2} \mathrm{O}$ with Double Helical Chain, Crystal Growth and Design, vol. 5, pp. 157-161.

[9] Li, P. and Liu, Z.H. 2011. Standard Molar Enthalpies of Formation for the Two Alkali Metal Borates, $\mathrm{Na}_{6}\left[\mathrm{~B}_{4} \mathrm{O}_{5}(\mathrm{OH})_{4}\right]_{3} \cdot 8 \mathrm{H}_{2} \mathrm{O}$ and $\mathrm{K}_{4}\left[\mathrm{~B}_{10} \mathrm{O}_{15}(\mathrm{OH})_{4}\right]$, Journal of Chemical and Engineering Data, vol. 56, pp. 102-105.

[10] Salentine, C.G. 1987. Synthesis, Characterization, and Crystal Structure of a New Potassium Borate, $\mathrm{KB}_{3} \mathrm{O}_{5} \cdot 3 \mathrm{H}_{2} \mathrm{O}$, Inorganic Chemistry, vol. 26, pp. 128-132.

[11] Liu, Z.H., Li, P., Li, L.Q. and Jia, Q.X. 2007. Synthesis, characterization thermochemistry
$\mathrm{K}_{2} \mathrm{~B}_{5} \mathrm{O}_{8}(\mathrm{OH}) \cdot 2 \mathrm{H}_{2} \mathrm{O}$, Thermochimica Acta, vol. 454, pp. 23-25.

[12] Alicilar, A., Okenek, F., Kayran, B. amd Tufak, M. 2015. Flame retardation, smoke suppression and antibacterial efficiencies of boron additives in styrene acrylic paints, Journal of the Faculty of Engineering and Architecture of Gazi University, vol. 30, pp. 701709.

[13] Svanson, S. and Forslind E. 1961. Nuclear magnetic resonance study of boron coordination in potassium borate glasses, Notes, pp. 174-175.

[14] Jun, L., Shuping, X. and Shiyang, G. 1995. FT-IR and Raman spectroscopic study of hydrated borates, Spectrochimica Acta Part A: Molecular and Biomolecular Spectroscopy, vol. 51A, pp. 519532.

[15] Yongzhong, J., Shiyang, G., Shuping X. and Lun, L. 2000. FT-IR spectroscopy of supersaturated aqueous solutions of magnesium borate, Spectrochimica Acta Part A: Molecular and Biomolecular Spectroscopy, vol. 56, pp. 1291-1297. 